\title{
E-governance role in raising the efficiency of performance within hospitals- King Fahd Specialist Hospital in Buraydah City-KSA
}

\author{
Ateeg Obaid Al-harbi \\ King Fahd specialist hospital-Buraydah city-Qassem-kingdom Saudi Arabia
}

\begin{abstract}
Information Technologies have created a Quantum leap in the fields of work development, Efficiency, Accuracy and increasing productivity. Computer and Internet were invested to execute numerous charts that used to be performed traditionally. Countries became more competitive about accomplishing people's daily life tasks through the World Wide Web. As a result of implementing Technology in executing the work and serving different types of services, the E-Management occurred in some of the countries that made this implementation a banner to serve its citizens regardless of their geographical location, standard of living or any other consideration, offering each individual the accessibility to the Internet, eliminating the so called "Digital Divide Line", and making the chances for an Internet access to all the citizens across the nation fair and equal. EManagement relies on the existence of an information society that depends on this technology to meet its needs. The Management must notice the importance of the ability of her citizens to deal with the Technology data, this will be achieved through different lanes that contributes in all the Governmental institutions (e.g., Hospitals, medical care units, social service centers and different ministries).For these logical reasons, the world automatically have begun shifting, looking forward to receive and provide the best for its people, and it was normal to apply this technology in international hospitals due to its important role in facilitating procedures and improving the efficiency of performance.
\end{abstract}

\section{Introduction}

The E-Management was described as a revolution in thinking and implementation and revolution to eliminate the waste of time, effort and resources, but this developed work method requires the establishment and dissemination of the necessary infrastructure to be used in communication and connectivity between hospitals and the Ministry of Health to develop and improve the management of public affairs which means the health services, both between the health authorities or between authorities and customers using informatics depending on internet in accordance with security guarantees to protect the beneficiary and the service owner like ministries and organizations, and linking them through the internet that links between the various competent authorities in accordance with certain standards.

\subsection{Research problem:}

The research problem is to acknowledge the reality of this information revolution, Communication Technology, and its achievements of a highly speed receiving and retrieving information, discussing the role of the E-Management improving the performance efficiency in organizations of different sectors and different managerial \& organizational levels with information quickly and easily.

Also to be the research problem is to recognize the effect of implementing E-Management in organizations on the employees' performance efficiency and on the E-Management of the service as a result.

\subsection{Research Significance:}

- Recognizing all issues and obstacles facing the implementation of the E-Management in organizations.

- The role of the E-Management in eliminating the elements of time and distance in different transactions.

- Recommending some solutions and suggestions supporting the importance of the implementation of the EManagement in organizations.

\subsection{Objective:}

2. Acknowledging the role of E-Management in the provision of E-Management health services in hospital.

3. Trends survey of the hospital staff in order to identify their attitudes towards some aspects of E-Management.

4. Proposals and recommendations benefit managers and technology specialist.

\section{Research Hypothesis:}

- $\quad$ There is a relation between the usage of the internet and the facilitating of obtaining data.

- Is there any relation between E-Management usage obstacles, computers and work accuracy in The Health Sector? 
- There is a relation between E-Management and improving performance in The Health Sector.

- There is a relation between Computer systems and E-Management in observing both work \& workers.

1.6 Research limitations:

1- Spatial limits:

Research applied in King Fahd Specialist Hospital in Buraydah City.

2- Temporal limits:

The second Semester of $1434 \mathrm{H}$

3- Humanitarian limits:

Officials and administrators at King Fahd Specialist Hospital in Buraydah.

\section{Leibrock Study [1994]}

\section{Background}

\{Computer - supported collaborative Work: Experiments in the polysemy of cognition, and education and learning organizations $\}$

The study aimed to identify the role of the information world wide web and progress in information Technology, the recent transformation in Management philosophies, the formation of working groups, and achieving new possibilities for computer-supported collaborative work.

The study sample consisted of a group of students from the University of Texas graduates who participated in the computer-supported collaborative work to choose the influence of personality traits and learning methods on their use of information technology.

Usage was chosen for personality type indicator and questionnaire for learning method.

The study showed the following results:

* The computer-supported collaborative work helps the highest administrative levels to realize the nature of work When participation in group projects.

* The lack of a statistically significant relationship between the variables of the study related to personality traits and learning methods for university students.

* This study agreed with the current study in the administrative aspects and differed in the study sample, where The study sample for Ieibrock consisted of university students, while the current study sample is consisting both Managers and staff of the Hospital.

\section{- Olsen \& Others study: [ 2004]}

\{Electronic Survey Administration Assessment in Twenty -First Century\}

This study aimed to:

- Test the application of the scientific advantages and disadvantages of E-logistics versus traditional administrative processes to study a large project.

- Evaluate the relationship between the harmonic electronic received information versus paperwork assembly procedures.

One of the study's major conclusions:

- Management techniques contribute to saving time and effort, through the great speed of the time it takes to pass Information, and access to information-rich results from the E-processes.

- The main downside is the material cost of computer programs, as well as the need to enormous technical support to run programs successfully.

That study agreed with the current study in concerning the use of computers in the completion of the administrative work and compared it with conventional methods, showing the most important obstacles facing its usage in the administrative area.

\section{1: Research Method}

\section{Methodology}

For this research. The researcher used a descriptive research method in this study. and analytical methods in collecting data and information through:

$\square \quad$ Theoretical study :

By referring to books and periodicals, references, previous studies concerning this topic.

Field study :

By designing a questionnaire and distribute it to the members of the study sample to know their views.

\section{2: Research Population and Sample}

A random sample of (25) employees of King Fahd Specialist Hospital in Buraydah city. 


\section{3: Data Collection Instrument}

The survey instrument used in this study is a questionnaire which developed from the researcher composed of eleven questions divided into three questions first personal information and other questions related to the subject of research

After the questionnaires were distributed to the participants present in the administrative offices a time official working hours from 8 am to 2 pm

\section{4: Data Collection Procedure}

Data collection. Will occur in the administrative offices and reception sections A letter will be sent to departments chiefs requesting their cooperation in using a few minutes of duty time to explain the research to administer the questionnaires. The questionnaires was distributed from 11/4/1434 to 25/4/ $1434 \mathrm{~h}$. 25 questionnaires was distributed and 20 questionnaires returned. The response rate was $80 \%$

\section{5: Data Analysis}

Statistical analysis will be performed with SPSS software, version 16.0. Categorical variables will be analyzed by simple frequency format. Standard deviation will be applied to percentages and quantitative and numerical variables.

\section{6 delimitations:}

Lack of time, which led to not study all previous studies. And there are a number of staff who does not have adequate knowledge of Acting computer which affects the results of the study.

1. Age :

\section{Results}

\begin{tabular}{|l|l|l|}
\hline Data & Frequency & Percent \\
\hline Less than 25 years old & 8 & $16 \%$ \\
\hline $25-30$ years old & 20 & $40 \%$ \\
\hline $30-40$ years old & 17 & $34 \%$ \\
\hline 40 years old and over & 5 & $10 \%$ \\
\hline Total & 50 & $100 \%$ \\
\hline
\end{tabular}

This table shows that $40 \%$ of the study sample between the ages of $25-30$ years old, and $34 \%$ between the ages of $30-40$ years old, and $16 \%$ less than 25 years old, and $10 \%$ aged 40 and over.

We conclude from this that the majority of the sample members are between the ages of 25 - 30 years old.

\section{Education :}

\begin{tabular}{|l|l|l|}
\hline Data & Frequency & Percent \\
\hline Primary & - & - \\
\hline Secondary & 2 & $4 \%$ \\
\hline University & 30 & $60 \%$ \\
\hline Higher education & 18 & $36 \%$ \\
\hline Total & 50 & $100 \%$ \\
\hline
\end{tabular}

This table shows that $60 \%$ of the study sample have bachelor university education, and $36 \%$ higher education, while $4 \%$ secondary.

We conclude from this that $96 \%$ of the sample members with university degrees and higher than the university, which assures us that they are familiar with the concept of E-Management.

3. Gender:

\begin{tabular}{|l|l|l|}
\hline Data & Frequency & Percent \\
\hline Male & 30 & $60 \%$ \\
\hline Female & 20 & $40 \%$ \\
\hline Total & 50 & $100 \%$ \\
\hline
\end{tabular}

This table shows that $60 \%$ of the sample were males, and $40 \%$ were females.

We conclude from this that $96 \%$ of the sample members are the ones who know what the E-Management.

4. The clarity of the E-Management concept:

\begin{tabular}{|l|l|l|}
\hline Data & Frequency & Percent \\
\hline clear & 11 & $22 \%$ \\
\hline not clear & 30 & $60 \%$ \\
\hline understandable & 9 & $18 \%$ \\
\hline Total & 50 & $100 \%$ \\
\hline
\end{tabular}


This table shows that $60 \%$ of the study sample see the clarity of the concept of E-Management, and to $22 \%$ the concept of E-Management is not clear, and to $18 \%$ is understandable ..

We conclude from this that $82 \%$ of the study sample assert that the administrative conflict affects the trends and tendencies of workers, leading to a low level of performance, so must work on reducing the administrative conflict.

\section{Is the E-Management applied in your administration?}

\begin{tabular}{|l|l|l|}
\hline Data & Frequency & Percent \\
\hline Yes & 24 & $48 \%$ \\
\hline Sometimes & 16 & $32 \%$ \\
\hline No & 10 & $20 \%$ \\
\hline Total & 50 & $100 \%$ \\
\hline
\end{tabular}

This table shows that $48 \%$ of the study sample say yes the E-Management is applied in their organization, and $32 \%$ say no, while $20 \%$ think sometimes delegating authority limits the administrative conflict.

We conclude from this that the majority of the study sample argue that E-Management is implemented in their organizations

6. Do you have a clear concept for E-Management?

\begin{tabular}{|l|l|l|}
\hline Data & Frequency & Percent \\
\hline Yes & 28 & $56 \%$ \\
\hline Sometimes & 5 & $10 \%$ \\
\hline No & 17 & $34 \%$ \\
\hline Total & 50 & $100 \%$ \\
\hline
\end{tabular}

This table shows that $56 \%$ of the study sample say yes they have clear concept of E-Management, and that $34 \%$ believe sometimes, and $10 \%$ think not.

We conclude from this that the majority of the sample of the study asserts that they have clear concept of EManagement.

7. Is the lack of funding is one of the obstacles to E-Management?

\begin{tabular}{|l|l|l|}
\hline Data & Frequency & Percent \\
\hline Yes & 28 & $56 \%$ \\
\hline Sometimes & 5 & $10 \%$ \\
\hline No & 17 & $34 \%$ \\
\hline Total & 50 & $100 \%$ \\
\hline
\end{tabular}

This table shows that $56 \%$ of the study sample say yes to lack of funding is one of the obstacles to EManagement, and that $34 \%$ believe sometimes, and $10 \%$ think not.

We conclude from this that the majority of the sample of the study argue that the lack of funding is one of the obstacles to E-Management.

8. What is your opinion about the most important requirements of the shift towards E-Management, and the effectiveness and success cofactors?

\begin{tabular}{|l|l|l|}
\hline Data & Frequency & Percent \\
\hline Developing and modernizing legislation & 28 & $56 \%$ \\
\hline Educating and training the work force & 5 & $10 \%$ \\
\hline Funding Abundance & 17 & $34 \%$ \\
\hline Strategic Planning & - & 2 \\
\hline Total & 50 & $100 \%$ \\
\hline
\end{tabular}

This table shows $56 \%$ of the study sample requirements of the shift towards E-Management, and the effectiveness and success cofactors is to develop and modernize legislation and $34 \%$ believe the education and training of work force, and that $10 \%$ believe the abundance of funding.

We conclude from this that the majority of the sample of the study contend that the requirements of the shift towards E-Management, and the effectiveness and success cofactors is developing and modernizing legislation.

9. Upgrading the skills of all Hospitals through E-Management:

\begin{tabular}{|l|l|l|}
\hline Data & Frequency & Percent \\
\hline Yes & 28 & $56 \%$ \\
\hline Sometimes & 5 & $10 \%$ \\
\hline No & 17 & $34 \%$ \\
\hline Total & 50 & $100 \%$ \\
\hline
\end{tabular}


This table shows that $56 \%$ of the study sample say yes to E-Management is upgrading the skills of all Hospitals, and $34 \%$ say sometimes, and $10 \%$ think not.

We conclude from this that the majority of the study sample argue that E-Management is upgrading the skills of all Hospitals.

10. E-Management helps to interact with Modern operations' systems within health departments and community:

\begin{tabular}{|l|l|l|}
\hline Data & Frequency & Percent \\
\hline Yes & 25 & $50 \%$ \\
\hline Sometimes & 8 & $16 \%$ \\
\hline No & 17 & $34 \%$ \\
\hline Total & 50 & $100 \%$ \\
\hline
\end{tabular}

This table shows that $50 \%$ of the study sample say yes E-Management helps to interact with modern operation systems within health departments and community, and 34\% say sometimes, and 16\% say no.

We conclude from this that the E-Management helps to interact with modern operation systems within health departments and community.

11. Do you think that E-Management is a result of the continuous interaction in the systems of computers?

\begin{tabular}{|l|l|l|}
\hline Data & Frequency & Percent \\
\hline Yes & 17 & $34 \%$ \\
\hline Sometimes & 10 & $20 \%$ \\
\hline No & 23 & $46 \%$ \\
\hline Total & 50 & $100 \%$ \\
\hline
\end{tabular}

This table shows that $34 \%$ of the study sample believe that E-Management is a result of the continuous interaction in the systems of computers, and $46 \%$ believe sometimes, while $20 \%$ believe not.

We conclude from this that the electronic management sometimes comes as a result of the continuous interaction in the systems of computers.

\section{Discussion}

1 - The information and communication revolution has contributed to a significant contribution in making a quantum leap in the lives of the nations.

2 - The E-Management eased the suffering of many citizens in requesting and obtaining the services.

3 - The E-Management has an effective goal to achieve, improve and develop the services provided, especially for university students through the computer.

4 - The shift toward electronic system discusses the many challenges in the Arab states.

5 - Field study showed people's consciousness to the requirements of the shift towards E-Management.

6 - The presence of a deep conviction in the sample's members of how important to shift towards EManagement concepts.

\section{Recommendations:}

1 - Must apply e E-Management on all hospitals to facilitate the provision of services to citizens.

2 - Must provide all means that support the success of E-Management in achieving its objectives.

3 - Must create a national information system directed towards E-Management and its concept.

4 - Researcher recommends reducing or eliminating the routine procedures that delay the process of transition towards electronic gateway.

5 - Increase training for hospital staff in the field of E-Management.

6 - Develop a system for stimulating (materialistic / Moral) the staff to use electronic technology.

7 - Increase guides explaining the mechanisms of E-Management implementation.

8 - Improve the necessary infrastructure for the E-Management implementation.

9 - Develop accurate and integrated databases.

10 - Increase the staff confidence in all E-transactions.

11 - Increase the number of specialists in operating and maintaining computers.

12 - Increase the English language skills for some of the hospital staff, and intensify the efforts of Arabization for all programs and computer applications.

13 - Increase financial allocations for all Managements to organize (lectures, seminars, workshops)

14 - Training staff to deal with E-Management applications efficiently. 


\section{References}

[1]. Ephraim Torian, James and Yathrib, Ephraim McLean, information technology in support of corporate governance, satisfaction of the Publishing House, Beirut, 2000.

[2]. Hassan Nazir Hrstana, the management of hospitals in Saudi Arabia, the Institute of Public Administration, Riyadh.

[3]. Hanan Abdel Rahim, continuous quality improvement in health organizations, public administration, 240 patrol period, 1421

[4]. Khalid bin Saad, total quality management applications on the health sector, Riyadh, 1418.

[5]. administrative patrol, No. Ninety-first, December 2002, the Sultanate of Oman.

[6]. Suhair Hassan, a lecture total quality management in hospitals, the Chamber of Commerce, Jeddah.

[7]. Talal Bin Abed Al Ahmadi, health care management, research center, the Institute of Public Administration in Riyadh, $1425,2004$.

[8]. Abdul Rahman Tawfiq, e-governance and the challenges of the future, Cairo, Center for Professional Management Expertise 2003.

[9]. Abdul Fattah Murad, electronic administration, Alexandria: pomp company, (date).

[10]. Fadwa girl Farouk, the use of international information network (Internet) in the management of higher education institutions in the Kingdom of Saudi Arabia, Riyadh, 1424.

[11]. Fahd bin Nasser bin Aboud Dham, electronic management between planning and implementation, Riyadh, King Fahd National Library, 2003 - 1424.

[12]. Mohammed Hassan Omar, management and technical partners in meeting the challenges of the Internet era, Cairo, 1997.

[13]. Mohamed Shaker Asfour, the origins of organization and methods, Institute of Management, Riyadh, 1993.

[14]. Mohammed Salah, Mohamed Ezzat, the application of total quality management in hospitals, Dar Khuraiji, Riyadh, 1422

[15]. Hisham Ctoah, computer and its uses in the administration, Dar Zahran, Jeddah in 2002. 